\title{
GROWTH DISPARITIES AMONG REGIONS OF THE VISEGRAD GROUP COUNTRIES: AN EVIDENCE OF THEIR EXTENT AND NATURE
}

\author{
Pavel Zdražil, Petra Applová
}

\section{Introduction}

Uneven regional development is generally understood as a problem of growing importance. Leaders of the European Union (EU) aim to actively address this issue, which can be manifested, for example, by the fact that one of the pivotal long-term and ongoing goals of EU regional policy is to combat regional disparities, which is directly based on Article 174 of the consolidated Treaty on the Functioning of the European Union (EU, 2010). In 2004 the EU extended eastwards, which further enhanced the importance of EU regional policy. Regions of the newly integrated and transformed former Eastern bloc countries had been less developed when compared to the existing EU 15 regions (with the exception of the capital city regions of Bratislava, Budapest and Prague). In terms of GDP per capita, as an indicator of economic performance, many of them have been on the same level as the least developed regions across the EU (Applová, 2014; Eurostat, 2015). These regions have not only become eligible recipients for funding from the European structural funds and from the Cohesion fund, but also the de facto platform for reviewing the effectiveness of redistribution mechanisms in terms of fulfilling the objectives of cohesion policy and partly also the efficiency of the entire European integration project. This fact has been documented by numerous recent studies that have focused on the progress of less developed countries and regions, as well as their inclusion in the EU (Dobrinsky \& Havlik, 2014; Cuaresma, Oberhofer, \& Vincelette, 2014; Forgó \& Jevčák, 2015; Zdražil, 2014).

This paper focuses on the Visegrad Group countries (the Czech Republic, Hungary, Poland, and Slovakia) that belong among the transformed economies of the former Eastern Bloc and whose regions can be generally regarded as less developed when compared with the regions of the traditional EU countries (EU 15). The aim of this paper is to assess the development of disparities in the economic performance among regions of the Visegrad Group countries, to identify the way in which economic growth factors determine these disparities, and partly to assess whether the integration of Visegrad Group countries into the European Union has affected the development of regional disparities in these countries.

\section{A Brief Review of Literature}

Of course, the economic theory says that the effects of economic integration are very ambiguous (Baldwin \& Wyplosz, 2006; Jovanovich, 2005; Krugman \& Venables, 1990). However, most authors do agree that the liberalization of the economic environment, in connection with integration, does at least develop the market, and increase pressure to achieve efficiency and higher living standards. Thanks to this it can generally be regarded as a beneficial phenomenon (Balassa, 1961; Fárek \& Kraft, 2006; Machlup, 1977). According to some studies the effects resulting from this integration are so unequivocally positive for the participating regions that the fact is indisputable (Olofsdotter \& Torstensson, 1998).

On the basis of the standard neoclassical model (Solow, 1956; Solow, 1957) and economic integration theory (Balassa, 1961), relatively less developed countries joining more advanced community should result in the acceleration of the less developed countries" growth and thus their convergence with the more developed countries. The argument in favour of convergence has been derived from neoclassical assumptions, stating that the liberalization of trade and mobility of production factors assumes that the balancing mechanism of price levels and income, or the convergence of (national or regional) economies will be 
activated (Martín Velázquez \& Funck, 2001), both of in terms of nominal and real convergence. It is therefore essentially a classic convergence hypothesis, on the basis of which notional grouping (convergence clubs) arise among regions, within which there is a significant convergence achieved in terms of productivity, and with that living standards (Baumol, Nelson, \& Wolff, 1994). One can therefore expect that the integration of less developed countries into the EU should be beneficial for these countries and their regions as it offers the potential to accelerate growth and to create positive conditions for their development (Capello, 2007), based not only on theoretical principles, but also through interventions in the form of redistribution mechanism within regional policy. On the other hand it must be said that economic integration can be accompanied by some really negative factors, especially when it involves relatively less developed regions. Most notably these include the so-called "brain-drain" in less developed regions (Lucas, 1988), sector concentration that can lead to a proliferation of monopolistic and oligopolistic structures (Perroux, 1969), or arguments arising from the New economic geography - especially spatial concentration, which leads to significant disparities (Krugman, 1991; Ottaviano \& Puga, 1998; Fujita \& Krugman, 2004).

There is large literature on growth processes and with the heavy focus on disparity issue across the European states. In this paper we follow especially the literature where the Visegrad Group states have been examined. We follow both the classical studies (Gardiner, Martin, \& Tyler, 2004; Barro \& Sala-i-Martin, 2004; Armstrong, 1995; BenDavid, 1999; Stiglitz, 1999; Fischer, Sahay, \& Vegh, 1998) and the recent studies (Monfort, 2008; Dobrinsky \& Havlik, 2014; Cuaresma et al, 2014; Tvrdoň, Tuleja, \& Verner, 2012; Marzinotto, 2012; Forgó \& Jevčák, 2015; Zdražil \& Kraftová 2012; Cuaresma, Oberhofer, Smits \& Vincelette, 2012; Vintrová \& Žd'árek, 2007; Geppert, Happich \& Stephan, 2008; Tvrdoň, 2010; Barca, 2009). The literature provides mixed results on the study of growth disparities - their extent and nature; based on different approaches and its main objectives. The key points and conclusions of the above-mentioned studies are discussed in the following text.

\section{Methodological Definition of the Research}

As a reference point for the analysis we chose regions at the NUTS II level, since NUTS II is the default level at which EU regional policy is implemented (European Commission, 2015). Within the Visegrad Group countries we are therefore working with a sample of 35 NUTS II regions, 8 of which are Czech, 7 Hungarian, 16 Polish, and 4 Slovak. The development of disparities is viewed in terms of the conventional concept of tracking coefficient of variation across the monitored sample of regions (1); therefore, it is a standard way of measuring the real disparities through $\sigma$-convergence (sigmaconvergence) (Barro \& Sala-i-Martin, 2004; Quah, 1996).

$$
C V=\frac{\sigma}{\mu^{\prime}}
$$

where coefficient of variation $(C V)$ is defined as the ratio of standard deviation $(\sigma)$ to the mean $(\mu)$.

As the main indicator of the development of economic disparities we chose gross domestic product per capita (GDP per capita), which is, being a measure of economic activity, a key indicator of changes in economic performance (Organisation for Economic Co-operation and Development [OECD], 2015b). Performance of economy, i.e. the economic growth, belongs to the main issues of economic theory and practice, and it is systematically emphasized by national governments as well as the EU strategies for development (Kraftová, Matěja, \& Prášilová, 2011). Drawing on the neoclassical growth model (Solow, 1956; Solow, 1957) we consider that economic growth is, in all its forms, derived from a pair of elementary factors of production - capital and labour and from the level of technology. In this study we focus mainly on the labour factor and the impact of its changes on the development of regional disparities. We have resorted to this partially restricting step because of a lack of available data that would have allowed us to explore in more detail, at a regional level of the Visegrad Group countries, the effect of changes resulting from the development of capital and its structures as well as changes arising from the advancement of technology.

In this paper, the GDP per capita growth is broken into two parts: "Productivity" and 
"Employment", which can basically be described as the basic attributes of regional competitiveness (Skokan, 2004). When monitoring changes in Productivity we use the approach of OECD (2015b), while monitoring changes in terms of "Labour productivity" (GDP per hour worked) and "Labour utilization" (hours worked). Also in terms of Employment we see the indicators in line with the definition of the OECD (2015a), when monitoring changes in the "Employment rate" (employed persons divided by the total working-age population) and "Labour force participation rate" (total workingage population divided by the total population) indicators. The multiplicative breakdown of the GDP per capita indicator, based on the above described key is shown in the following equation (2).

$$
\begin{aligned}
& \frac{\text { (PDP }}{\text { population }}=\left(\frac{\frac{\text { GDP }}{\text { hoursworked }} \cdot \text { hours worked }}{\text { employment }}\right) \text {. } \\
& \text { (Employment) } \\
& \left(\frac{\text { employment }}{\text { ea population }} \cdot \frac{\text { ea population }}{\text { population }}\right)
\end{aligned}
$$

Based on the studies of other authors we can prospectively assume that productivity will be the dominant determinant of growth in monitored regions (Cuaresma et al, 2012; Baumol, 1986; Gardiner et al, 2004; Barro \& Sala-i-Martin, 2004). For this reason we have chosen a less detailed breakdown of the Employment part; conversely, we have been quite aware of the desirability to classify the Productivity part in detail because, as aptly described by Paul Krugman (1997): "Productivity isn't everything, but in the long run it is almost everything". However, due to the above indicated unavailability of data on the stock of the regional capital we can proceed to a more detailed breakdown of the Productivity part into productivity resulting from labour, capital, or residual factors, or into multi-factor productivity. For these reasons we will monitor disparities in the economic performance of regions only within the "limited" context of the above outlined breakdown (2).

We have chosen the year 2000 to be the initial year of our analysis as we do not consider it appropriate to distort the analysis by including the very dynamic period of the 1990s, during which the Visegrad Group countries faced fundamental political, social, and economic changes. The period of transformation of the national economies from a centrally planned system to a market system was, among other things, coupled with high fluctuations in the volume of production and core changes in its structure and in employment, as well as with unstable price levels, fundamental changes in the ownership structure, the development of legislative framework, etc. (Fischer et al, 1998; Stiglitz, 1999). Therefore, the analysis has been prepared for the period 2000-2013, and given the objective of this article, we have paid special attention to the sub-period 2004-2013, i.e. after the entry of the Visegrad Group countries into the EU.

\section{Development of Regional Disparities in the Visegrad Group Countries}

Before embarking on the analysis of the development of disparities in regional economic performance, and the sources of these disparities, it is appropriate to briefly outline the development of regions within the Visegrad Group countries in relation to the EU average values. Whether in terms of the development of the regions there is a tendency towards fulfilling the objectives of cohesion policy by balancing the economic disparities, or whether in reality the objectives are not met. A simplified illustration of the tendencies in the development of the GDP per capita disparities between regions of the Visegrad Group countries and the current EU average (EU 28) for the period 2000-2013 and also for the shortened period 2004-2013, which represents the integration period of the Visegrad Group countries within the EU, is captured in Tab. 1. The tendencies in the development of disparities are captured through the absolute value of the difference between the ratio of GDP per capita of the region and the GDP per capita of the EU 28 average at the interval borders. It is therefore a very rough and rather tentative illustration that, based on annual comparison, shows by how many percent the regions have converged towards the EU 28 average value during a given period or have diverged from it.

Based on the results captured in Tab. 1 we can say that during the 2004-2013 period only 7 regions did not converge towards the EU 28 average value (CZ01 - Prague, CZ02 - Central Bohemia, CZ03-Southwest, CZ04-Northwest, 


\begin{tabular}{|c|c|c|c|c|c|c|c|c|c|}
\hline \multirow{3}{*}{ region } & \multicolumn{9}{|c|}{$\begin{array}{l}\text { Development of disparities in terms of GDP per capita between Visegrad Group } \\
\text { regions and the EU } 28 \text { average }(2000-2013 ; 2004-2013)\end{array}$} \\
\hline & trend & $\begin{array}{c}\text { change } \\
\text { (in \%) }\end{array}$ & trend & $\begin{array}{c}\text { change } \\
\text { (in \%) }\end{array}$ & region & trend & $\begin{array}{c}\text { change } \\
\text { (in \%) }\end{array}$ & trend & $\begin{array}{c}\text { change } \\
\text { (in \%) }\end{array}$ \\
\hline & \multicolumn{2}{|c|}{$2000-2013$} & \multicolumn{2}{|c|}{ 2004-2013 } & & \multicolumn{2}{|c|}{$2000-2013$} & \multicolumn{2}{|c|}{ 2004-2013 } \\
\hline CZ01 & D & 31.1 & D & 6.1 & PL22 & $C$ & 19.9 & $C$ & 14.8 \\
\hline CZO2 & $\mathrm{C}$ & 0.9 & D & -2.9 & PL31 & $\mathrm{C}$ & 13.7 & $\mathrm{C}$ & 12.4 \\
\hline CZO3 & $\mathrm{C}$ & 5.1 & D & -0.6 & PL32 & $\mathrm{C}$ & 13.6 & $\mathrm{C}$ & 11.9 \\
\hline CZO4 & $\mathrm{C}$ & 2.3 & D & -2.1 & PL33 & $\mathrm{C}$ & 12.5 & $\mathrm{C}$ & 10.2 \\
\hline CZO5 & $\mathrm{C}$ & 2.9 & $C$ & 1.3 & PL34 & $\mathrm{C}$ & 14.2 & $\mathrm{C}$ & 12.5 \\
\hline CZO6 & $\mathrm{C}$ & 14.2 & $C$ & 8.4 & PL41 & $\mathrm{C}$ & 22.6 & $\mathrm{C}$ & 19.6 \\
\hline CZ07 & $\mathrm{C}$ & 8.4 & $C$ & 4.7 & PL42 & $\mathrm{C}$ & 10.3 & $\mathrm{C}$ & 12.4 \\
\hline CZ08 & $\mathrm{C}$ & 13.6 & $\mathrm{C}$ & 5.5 & PL43 & $\mathrm{C}$ & 14.6 & $\mathrm{C}$ & 12.4 \\
\hline HU10 & $\mathrm{C}$ & 25.2 & D & 8.8 & PL51 & $\mathrm{C}$ & 27.1 & $\mathrm{C}$ & 25.8 \\
\hline HU21 & $\mathrm{C}$ & 7.6 & $C$ & 0.4 & PL52 & $\mathrm{C}$ & 15.2 & $\mathrm{C}$ & 12.4 \\
\hline HU22 & $\mathrm{C}$ & 7.6 & $\mathrm{C}$ & 3.2 & \begin{tabular}{|l} 
PL61 \\
\end{tabular} & C & 13.3 & C & 12.1 \\
\hline HU23 & $\mathrm{C}$ & 4.9 & $\mathrm{C}$ & 1.2 & PL62 & $\mathrm{C}$ & 12.3 & $\mathrm{C}$ & 11.3 \\
\hline HU31 & $\mathrm{C}$ & 5.3 & D & -0.9 & PL63 & $\mathrm{C}$ & 18.6 & $\mathrm{C}$ & 16.6 \\
\hline HU32 & $C$ & 7.3 & $\mathrm{C}$ & 2.1 & SK01 & D & 77.1 & D & 56.4 \\
\hline HU33 & $\mathrm{C}$ & 4.9 & $\mathrm{C}$ & 1.2 & SK02 & $C$ & 24.2 & C & 17.3 \\
\hline PL11 & C & 20.9 & C & 17.5 & SK03 & $C$ & 19.0 & $C$ & 13.6 \\
\hline PL12 & $C$ & 35.2 & $C$ & 32.7 & SK04 & $\mathrm{C}$ & 14.6 & $C$ & 10.2 \\
\hline PL21 & $C$ & 17.1 & $C$ & 15.9 & & & & & \\
\hline
\end{tabular}

Notes: $\mathrm{C}$ stands for convergence; D represents divergence; negative values indicate that the region at first converged towards the average value from the "top" and after reaching it, diverged "downwards".

Source: authors' own work based on Eurostat (2015)

HU10 - Central Hungary, HU31 - Northern Hungary and SK01 - Bratislava Region). The findings confirm prevailing convergence to the EU 28 average and can be described as totally compatible with the findings of many other studies that dealt with the development of disparities in transformed economies (Dobrinsky \& Havlik, 2014; Cuaresma et al., 2012; Forgó \& Jevčák, 2015). Excluding capital regions (CZ01, HU10 and SK01), where the measured deviation from the average value was positive, the measured negative deviation in CZO2, CZ03, CZO4, and HU31 regions was relatively low - in all cases within 3 percentage points. It is also interesting that disparities - whether in a positive or negative direction - are connected to four Czech regions, or to half of all Czech regions. In contrast, in other countries, the resulting divergence tendencies were very rare and mostly related to the capital region, where a positive deviation represent divergence due to higher economic performance, which basically corresponds with the reasoning presented by the economists of the New Economic Geography movement, who stated that economic activities are concentrated in the central agglomerations (Krugman, 1991; Fujita \& Krugman, 2004; Ottaviano \& Puga, 1998). Although in the case of metropolitan regions this phenomenon goes directly against the convergence hypothesis, it certainly cannot be taken as an indication of an undesirable development because these regions are important centres of development with a significant influence on the development of other regions within the country, and at the same time they are some of the most economically powerful regions across the EU (Eurostat, 2015). 
The accession of the Czech Republic to the European integration project in the context of general growth trend and the associated convergence of regions of other Visegrad Group countries to the EU 28 average looks the least positive (just because the actual growth does not match the rate of other European regions and therefore, in terms of disparities development, does not contribute to the convergence, it probably would not be appropriate, at this stage, to mark the development of Czech regions as outright negative). The findings that a substantial number of Czech regions did not develop in a very positive way during their integration into the EU takes on a further dimension when we take into account the relatively short period before the country joined the EU (2000-2004). Tab. 1 clearly shows that during the period 2004-2013 the convergence trend was considerably weaker when compared to the period 2000-2013. It is quite logical to measure lower differences for sub-periods when considering a relatively steady development, but the actually recorded changes are for most regions significantly lower and proportionally they do not correspond to the extent of the shortening of the period. Virtually identical conclusions can be drawn for the development of disparities among Hungarian regions, where the measured convergence trend in the period 2004-2013 was also significantly weaker when compared with the period 2000-2013. Conversely, in the case of Polish and Slovak regions the conclusions regarding a significant slowdown in convergence after the countries joining the EU do not apply. Based on measurements we can conclude that for a number of Slovak and Polish regions the convergence trend towards the EU 28 average has been rather even; in the case of some Polish regions it even seems that the pace of the convergence process in the period 2004-2013 slightly accelerated. The detected existence of analogies in the trends of regional disparity development for the two pairs of countries Czech Republic-Hungary and Poland-Slovakia is confirmed by the findings of another study by Zdražil and Kraftová (2012), who moreover believe, based on the analysis of the period 1999-2008, that the NUTS II regions of the mentioned pairs diverged from each other, especially in the period before joining the EU. Although the above view of the development of regional economic disparities of the Visegrad Group countries is somewhat limited, the conclusions appear to be very problematic in terms of fulfilling the EU cohesion policy objectives. Although there has been quite an obvious convergence of most regions to the EU 28 average, the question is to what extent has this convergence been caused by the integration, and to what extent would this have happened spontaneously.

\subsection{Development of Disparities in Terms of $\sigma$-convergence}

Based on results of the empirical measurements captured in Fig. 1, we can say that the extent of disparities in the economic performance among regions of the Visegrad Group countries after their accession to the EU (2004) grew up to 2007, although the trend had been there since the beginning of the analyzed period (2000). Subsequently, we can say that the trend changed to convergence, and although in 2011 the extent of disparities among Visegrad Group's regions was comparable with 2004, it was reduced in subsequent years. This is somewhat confirmed by the findings of some earlier studies that defend the hypothesis of convergence among European regions (Monfort, 2008; Armstrong, 1995; Geppert et al, 2008), especially among the transformed regions of the Central and Eastern European countries, or the Visegrad Group (Vintrová \& Žd'árek, 2007; Tvrdoň, 2010). At the same time, the findings showing that the convergence trends only started in the period after the Visegrad Group countries had joined the EU, are largely compatible with the conclusions of the Ben-David (1999) study that showed that liberalization of the economic environment together with integration are the factors that significantly contributes to the convergence. Therefore, the accession to the EU can be seen as an impulse that greatly encouraged the process of convergence in the environment of the former Eastern bloc countries (Dobrinsky \& Havlik, 2014).

The economic crisis and the extent of its influence on the performance of individual economies certainly had a significant effect on the observed convergence of Visegrad Group regions. For example Tvrdoň et al (2012) show in this context that within the Visegrad Group countries the development of the economic performance of Poland was clearly the least affected by the economic crisis. Considering 
that Polish regions account for almost half of the sample and are generally considered less developed, the actual contribution of integration to convergence, which has been apparent since the beginning of the economic crisis, is largely disputable.
However, looking at the development of regional disparities in individual Visegrad Group countries, it seems that in the period following the accession of the countries to the $\mathrm{EU}$, from the national point of view, the regional disparities steadily grew. This growing trend

\section{Fig. 1: $\sigma$-convergence of GDP per capita, the Visegrad Group and its countries (2000-2013)}

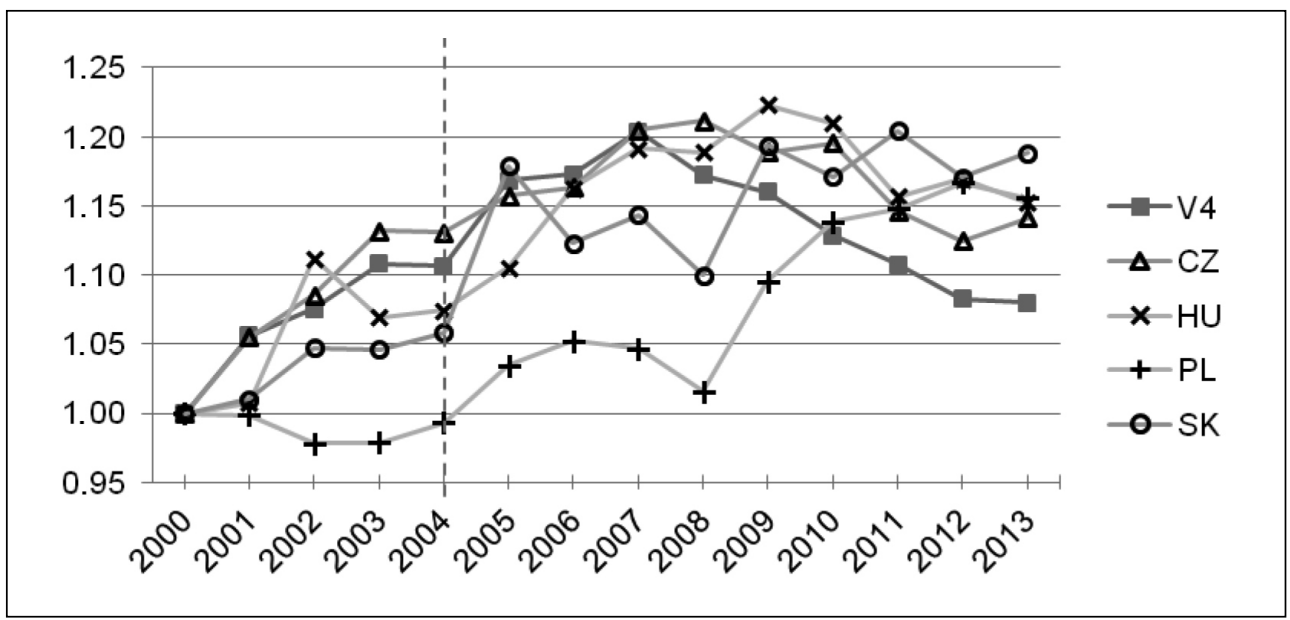

Source: authors' own work based on Eurostat (2015)

only started to turn in 2009 for the Czech, Hungarian, and Slovak regions, while the Polish regions remained unchanged with the increase in disparities continuing. Within the monitored sub-period before the accession of the Visegrad Group countries to the EU (2000-2004) it can also be argued that the development of regional disparities in the Czech Republic, Hungary, and Slovakia was pretty similar - i.e. growing; however, among Polish regions there was no increase in disparities. In accordance with the above described situation, in terms of regions across the Visegrad Group, this finding seems somewhat illogical; however, it is fully compatible with the findings of some recent studies on the effectiveness of the European cohesion policy that agree on the fact that although across the EU both countries and regions rather converge, internally for many countries divergence is more common (Barca, 2009; Geppert et al, 2008; Marzinotto, 2012).

\section{Natures of Regional Disparities in the Visegrad Group Countries}

Whatever the trends regarding the development of regions within the Visegrad Group countries, it is entirely appropriate to ask the question: what is their nature? For only with this knowledge is it then possible to make an effort to actively influence the development of disparities through the application of regional policy instruments. Therefore, in the following subsections we analysed the economic growth in regions of the Visegrad Group countries in order to try and discover the differences in the components of growth in the individual countries, how they determine the economic development, and to what degree they are responsible for the differences in the development of disparities as demonstrated by Fig. 1 above.

The analysis is divided into four parts, one for each country in the sample, followed by a brief summary of the main findings. 
Our motivation for presenting the results for individual countries stems from the fact that there are large differences in growth between the regions across the Visegrad Group states while the inner-country differences are much more similar (see Tab. 1 above). We guess it can be due to the differences in regional policy principles applied in individual countries as well as the result of uneven levels of GDP per capita and its growth components in regions of individual countries. Even though we are aware of desirability of revealing the origins of growth disparities within the components that we have examined, we guess this issue is far behind the purpose of this paper which is rather answer the truly crucial question on: How are the disparities caused by its main components? Answering this initial question enables one to start intentionally aimed analysis that should bring relevant findings and recommendations for individual countries and help to shape the most appropriate regional policy objectives.

\subsection{Czech Regions}

As shown clearly in Tab. 2 the disparities in the development of the GDP per capita indicator among the Czech NUTS II regions can hardly be considered dynamic during 2004-2013. This period can be divided into two halves, in the first half (2004-2008) the extent of the measured disparities grew slowly, while in the second half (2009-2013) it gradually declined. When we take into account the development of disparities before the Czech Republic joined the EU, we can see that a gradual increase in disparities had already occurred in this period, i.e. from the starting point of the analysis - from the year 2000 . Therefore, it can be concluded that disparities in the economic performance among the Czech regions had (relatively) grown over the long term, and this trend continued even after the Czech Republic's entry into the EU. However, at present (or in the last reporting period), regional disparities in terms of GDP per capita have reached a comparable level with that of when the Czech Republic joined the EU. Therefore, it can be speculated that the trend in the development of economic disparities has changed and a new phase of a gradual decrease of disparities has started. Dobrinsky and Havlik (2014) consider the relative high level of development of the Czech regions to be the cause of their convergence; this is reflected in a lower rate of GDP growth, especially when compared to Poland and Slovakia. At the same time it can be argued that, although the extent of disparities among regions of the Czech Republic is lower in comparison with other countries of the Visegrad Group (see Fig. 1 above), the trends of the observed subsample (Czech regions) are very similar to the trends of the whole sample (Visegrad Group regions).

When looking at the breakdown of the GDP per capita, it is clear that the dominant components primarily responsible for the disparities in the economic performance of regions are the disparities in productivity. When breaking down the overall productivity in accordance with the procedure defined above (2), it is obvious that Labour productivity - GDP per hour worked - can without a doubt be considered the central determinant of disparities. The share of Labour productivity disparities within the GDP per capita disparities grew during the monitored period in the Czech regions. In terms of absolute contribution to disparities it can be argued that the development of Labour productivity disparities largely follows the development of the GDP per capita disparities. This similarity is naturally completely logical considering the mentioned deterministic relationship between the two indicators. Although, in absolute terms, the highest disparity in Labour productivity was measured in 2008, the same as with GDP per capita; there was no decrease in the disparities in Labour productivity to the level of 2004 by the end of the reporting period.

In relative terms, an increase in the contribution of Labour productivity to the overall disparities in GDP per capita within the Czech regions can be clearly concluded. To the contrary, other economic performance factors - Labour utilization and Employment rate displayed convergence trends. The contribution of these two factors to the disparities in economic performance is indeed very low; therefore, the effect of these factors on the convergence of Czech regions, compared with the total extent of disparities in GDP per capita, can be regarded as insignificant but still existing. Regarding the Labour participation rate within the period of 2004-2013 we can speak of a relatively stable development of disparities with a deviation between 2009 and 2010. If we include the subperiod before the Czech Republic joined to the EU, i.e the total period since 2000, then we could talk from an overall perspective about very 


\begin{tabular}{|c|c|c|c|c|c|c|c|c|c|c|c|c|c|c|}
\hline \multirow[t]{2}{*}{ Tab. 2: } & \multicolumn{14}{|c|}{$\begin{array}{l}\text { Czech regions - } \sigma \text {-convergence of GDP per capita and its breakdown } \\
(2000-2013)\end{array}$} \\
\hline & 2000 & 2001 & 2002 & 2003 & 2004 & 2005 & 2006 & 2007 & 2008 & 2009 & 2010 & 2011 & 2012 & 2013 \\
\hline GDP per capita & .364 & .384 & .396 & .413 & .412 & .422 & .424 & .439 & .442 & .433 & .436 & .418 & .410 & .416 \\
\hline \multicolumn{15}{|c|}{ Productivity changes } \\
\hline Labour productivity & .266 & .284 & .305 & .322 & .324 & .334 & .334 & .362 & .369 & .354 & .359 & .353 & .342 & .353 \\
\hline in $\%$ & 73.0 & 74.0 & 77.1 & 78.0 & 78.7 & 79.3 & 78.7 & 82.3 & 83.6 & 81.8 & 82.4 & 84.6 & 83.5 & 84.9 \\
\hline Labour utilization & .024 & .024 & .018 & .019 & .018 & .015 & .021 & .019 & .020 & .016 & .012 & .013 & .010 & .010 \\
\hline in $\%$ & 6.6 & 6.2 & 4.6 & 4.7 & 4.4 & 3.6 & 4.8 & 4.3 & 4.6 & 3.8 & 2.9 & 3.0 & 2.4 & 2.4 \\
\hline \multicolumn{15}{|c|}{ Employment changes } \\
\hline Employment rate & .042 & .040 & .034 & .035 & .038 & .041 & .037 & .026 & .022 & .026 & .027 & .021 & .026 & .025 \\
\hline in $\%$ & 11.5 & 10.3 & 8.7 & 8.5 & 9.2 & 9.8 & 8.7 & 5.8 & 4.9 & 6.1 & 6.1 & 5.1 & 6.4 & 5.9 \\
\hline $\begin{array}{l}\text { Labour parti-cipation } \\
\text { rate }\end{array}$ & .032 & .036 & .038 & .036 & .032 & .031 & .033 & .033 & .030 & .036 & .038 & .031 & .031 & .028 \\
\hline in $\%$ & 8.8 & 9.5 & 9.6 & 8.8 & 7.7 & 7.3 & 7.8 & 7.5 & 6.9 & 8.3 & 8.7 & 7.3 & 7.6 & 6.8 \\
\hline
\end{tabular}

Source: authors' own work based on Eurostat (2015)

mild convergence trends; however, this trend is not entirely clear. In summary it can probably be said that the high contribution of Labour productivity disparities to the disparities in the economic performance of the Czech regions has not only been due to the development of the Labour productivity disparities, but also partly due to the development tendencies mainly convergence - of other factors that have been to a greater or lesser extent responsible for the disparities in GDP per capita.

\subsection{Hungarian Regions}

In terms of the development of disparities in economic performance, the Hungarian regions exhibit partially analogous tendencies with the Czech regions, and considering the above, even with the entire sample of Visegrad Group regions. Thus, at first, there was a gradual increase in disparities from the starting point of the analysis (2000) that lasted even after Hungary joined the EU (2004), then the highest level of disparities was reached in 2009 - i.e. with some delay compared with the Visegrad Group and the Czech Republic - and consequently since then the disparities in the regional economic performance have been decreasing (see Tab. 3). However, besides the fact that the disparities among Hungarian regions have been lower in comparison with the Czech regions, the decrease in disparities at the end of the monitored period was not such that they dropped to the level at which they were when Hungary joined the EU.

When measuring the sources of disparities in GDP per capita among Hungarian regions, we found that Labour productivity was again a significant determining component and that its significance steadily grew over time. And, although the contribution of Labour productivity to the disparities in GDP per capita is relatively high, it is not that dominant in comparison with the Czech regions. Furthermore, there is higher contribution of Labour participation rate apparent in Tab. 3, which means a convergence of existing disparities among Hungarian regions, and at the same time a reduction in the contribution to the total disparities in economic performance; however, compared with the contribution of this factor to the disparities among Czech regions the level of contribution here was initially almost threefold, and at the end of the 2000-2013 period approximately twice as high. In terms of Labour utilization we can confirm a very low range of regional disparities (the lowest within the Visegrad Group countries), which is associated with convergence, throughout the 2000-2013 period. The contribution of Labour utilization disparities to the disparities in GDP per capita gradually lost its importance. The development of the Employment rate disparities during the 2000-2006 period was characterized by oscillations of a value around 


\begin{tabular}{|c|c|c|c|c|c|c|c|c|c|c|c|c|c|c|}
\hline $\begin{array}{l}\text { Hun } \\
(200\end{array}$ & -2 & re & ns & $-c$ & $\mathrm{e}$ & nc & $t$ & $p$ & ca & $\mathbf{a}$ & ts & ea & vn & \\
\hline & 2000 & 2001 & 2002 & 2003 & 2004 & 2005 & 2006 & 2007 & 2008 & 2009 & 2010 & 2011 & 2012 & 2013 \\
\hline GDP per capita & .330 & .332 & .367 & .352 & .354 & .364 & .383 & .393 & .392 & .403 & .399 & .381 & .385 & .380 \\
\hline \multicolumn{15}{|c|}{ Productivity changes } \\
\hline Labour productivity & .210 & .229 & .254 & .247 & .245 & .253 & .277 & .284 & .286 & .307 & .317 & .291 & .289 & .296 \\
\hline in $\%$ & 63.7 & 69.1 & 69.2 & 70.0 & 69.2 & 69.3 & 72.2 & 72.3 & 72.9 & 76.1 & 79.4 & 76.2 & 75.1 & 78.0 \\
\hline Labour utilization & .011 & .009 & .010 & .010 & .009 & .007 & .008 & .006 & .007 & .006 & .007 & .009 & .006 & .005 \\
\hline in $\%$ & 3.4 & 2.6 & 2.8 & 2.7 & 2.6 & 2.0 & 2.2 & 1.5 & 1.7 & 1.5 & 1.8 & 2.3 & 1.7 & 1.3 \\
\hline \multicolumn{15}{|c|}{ Employment changes } \\
\hline Employment rate & .022 & .018 & .018 & .020 & .018 & .020 & .024 & .031 & .035 & .031 & .028 & .033 & .029 & .023 \\
\hline in $\%$ & 6.7 & 5.6 & 5.0 & 5.7 & 5.0 & 5.4 & 6.3 & 7.9 & 9.0 & 7.8 & 7.0 & 8.6 & 7.6 & 6.2 \\
\hline $\begin{array}{l}\text { Labour parti-cipation } \\
\text { rate }\end{array}$ & .086 & .076 & .085 & .076 & .082 & .085 & .074 & .072 & .065 & .059 & .047 & .049 & .060 & .055 \\
\hline in $\%$ & 26.2 & 22.7 & 23.1 & 21.6 & 23.2 & 23.3 & 19.3 & 18.3 & 16.5 & 14.6 & 11.8 & 12.9 & 15.7 & 14.5 \\
\hline
\end{tabular}

Source: authors' own work based on Eurostat (2015)

0.20 , then there was a sudden increase coupled with oscillations of around 0.30 . The value measured in the last year of the analysis (2013) suggests a reduction in the extent of disparities, but the question is whether this is the beginning of a new trend or merely a temporary deviation. Generally, the development of Employment rate disparities can be described as rather growing and therefore contributing to the increase in the disparities in GDP per capita among Hungarian regions, which is also evident when looking at the development in terms of absolute and relative contributions (see Tab. 3 ).

\subsection{Polish Regions}

The development of disparities that are reflected in Tab. 4 clearly shows that the extent of disparities in GDP per capita among the Polish regions is definitely the lowest within the Visegrad Group. At the same time the development of these disparities stands out the most in comparison with the other Visegrad Group countries (this fact is well demonstrated by Fig. 1 above). In other words, regional disparities within Czech, Hungarian, and Slovak regions had grown steadily before and after 2004 (and with greater intensity than was the case in Polish regions) and only since 2009 can we talk about their stabilization, or perhaps even a change of trend and a gradual reduction of disparities among regions. In contrast, in the case of the Polish regions we can talk about a relatively stable development of disparities until 2004, followed by a period of increased divergence. We also cannot claim, based on the measurements captured in Tab. 4 that in the case of Polish regions there was a peak and a subsequent stabilization, or even a reversal in the trend, or a starting convergence.

Regarding the causes of the disparities, it is evident looking at Tab. 4 that even in the case of Polish regions the disparities in Labour productivity per unit of time, i.e. in GDP per hour worked, are primarily responsible for the extent of disparities in GDP per capita. However, both in absolute terms and in relative terms, the contribution of this component to the disparities in GDP per capita is clearly the lowest within the Visegrad Group countries - about twothirds in relation to the Hungarian disparities, about a half in relation to the Czech, and a third in relation to the Slovak regional disparities. From this perspective Polish regions can be marked as the least varied within the Visegrad Group. In terms of an absolute contribution to the disparities in economic performance of Polish regions the development of Labour productivity disparities largely correlates with the development of disparities in GDP per capita - a relatively stable development during the period preceding the country joining the $\mathrm{EU}$ is followed by a change in the trend and growing disparities in the following years. However, in relative terms the development of 


\begin{tabular}{|c|c|c|c|c|c|c|c|c|c|c|c|c|c|c|}
\hline $\begin{array}{l}\text { Pol } \\
(20\end{array}$ & $\begin{array}{l}h \mathrm{re} \\
-20\end{array}$ & $\begin{array}{l}\text { on } \\
\text { ) }\end{array}$ & $\sigma$ & $\mathbf{V}$ & er & of & $P$ & $\mathbf{C}$ & $a$ & its & e & 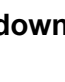 & & \\
\hline & 2000 & 2001 & 2002 & 2003 & 2004 & 2005 & 2006 & 2007 & 2008 & 2009 & 2010 & 2011 & 2012 & 2013 \\
\hline GDP per capita & .209 & .209 & .204 & .205 & .208 & .216 & .220 & .219 & .212 & .229 & .238 & .240 & .244 & .242 \\
\hline \multicolumn{15}{|c|}{ Productivity changes } \\
\hline Labour productivity & .123 & .123 & .123 & .122 & .114 & .130 & .131 & .127 & .121 & .138 & .148 & .142 & .145 & .144 \\
\hline in $\%$ & 58.7 & 58.8 & 60.0 & 59.5 & 54.8 & 60.1 & 59.5 & 58.0 & 56.9 & 60.4 & 62.3 & 59.2 & 59.6 & 59.7 \\
\hline Labour utilization & .016 & .019 & .015 & .016 & .018 & .019 & .016 & .016 & .014 & .016 & .013 & .013 & .015 & .015 \\
\hline in $\%$ & 7.6 & 9.1 & 7.3 & 7.6 & 8.7 & 8.7 & 7.4 & 7.3 & 6.7 & 6.8 & 5.4 & 5.6 & 6.2 & 6.0 \\
\hline \multicolumn{15}{|c|}{ Employment changes } \\
\hline Employment rate & .019 & .021 & .027 & .023 & .025 & .020 & .013 & .009 & .008 & .011 & .009 & .010 & .011 & .012 \\
\hline in $\%$ & 9.1 & 10.3 & 13.1 & 11.4 & 12.0 & 9.0 & 5.8 & 4.1 & 4.0 & 4.8 & 3.9 & 4.2 & 4.7 & 4.9 \\
\hline $\begin{array}{l}\text { Labour parti-cipation } \\
\text { rate }\end{array}$ & .051 & .046 & .040 & .044 & .051 & .048 & .060 & .067 & .069 & .064 & .068 & .074 & .072 & .071 \\
\hline in $\%$ & 24.6 & 21.8 & 19.6 & 21.4 & 24.4 & 22.2 & 27.4 & 30.6 & 32.4 & 27.9 & 28.4 & 31.0 & 29.5 & 29.4 \\
\hline
\end{tabular}

Source: authors' own work based on Eurostat (2015)

disparities among Polish regions in comparison with the development of disparities among regions of other Visegrad Group countries is totally unique - there is in fact no increase in the proportion of Labour productivity disparities within the GDP per capita disparities, but the amount of this proportion oscillated (with rare exceptions) within the range of 2.5 percentage points throughout the period 2000-2013. In practical terms this means that the growth of disparities in the economic performance of Polish regions must be attributed to at least one other significant factor in addition to the growth of disparities in Labour productivity. At the same time it is also clear that in terms of growth of disparities in GDP per capita the Labour productivity factor is not the most important determinant; based on the values recorded in Tab. 4 that position has been taken by the Labour participation rate.

The development of disparities in the Labour participation rate to some extent also correlates with the development of disparities in GDP per capita (as well as with Labour productivity) i.e. they only started to increase after Poland's accession to the EU. It is therefore quite the opposite development to the development of regional disparities in other Visegrad Group countries. This fact is clearly demonstrated by the increasing contribution of Labour participation rate disparities to the disparities in economic productivity among Polish regions.
In terms of Employment rate in Polish regions one can undoubtedly talk about convergence, especially in the post-entry period; in terms of Labour utilization there is no clear trend of either convergence or divergence. However, in general, both these factors (Employment rate and Labour utilization) have very low and continuously decreasing impact on the extent of disparities in economic productivity among Polish regions.

\subsection{Slovak Regions}

As already partially implied above, the development of disparities in economic productivity among Slovak regions is in terms of $\sigma$-convergence measurement rather similar to Czech and Hungarian regions than to Polish regions. This statement is not only illustrated by Fig. 1 (see above) but it is also backed up by the results presented in Tab. 5 . Since the beginning of the monitored period (2000) there has been an increase in disparities in GDP per capita among the Slovak regions. The extent of disparities among the Slovak regions is the highest within the Visegrad Group, and at the same time the development of these disparities is generally the most dynamic. However, the outlined situation could to some extent be caused by the lowest count of Slovak regions; therefore, it is necessary to consider this part of the analysis to be the most limited. Given the above dynamics of disparities in 


\begin{tabular}{|c|c|c|c|c|c|c|c|c|c|c|c|c|c|c|}
\hline $\begin{array}{l}\text { Slo } \\
(200\end{array}$ & $\begin{array}{l}k r \\
-2(\end{array}$ & ) & $\boldsymbol{\sigma}$ & ni & el & of & $\mathbf{P}$ & C & a & it & re & & & \\
\hline & 2000 & 2001 & 2002 & 2003 & 2004 & 2005 & 2006 & 2007 & 2008 & 2009 & 2010 & 2011 & 2012 & 2013 \\
\hline GDP per capita & .495 & .500 & .518 & .518 & .524 & .583 & .556 & .566 & .544 & .591 & .579 & .596 & .579 & .588 \\
\hline \multicolumn{15}{|c|}{ Productivity changes } \\
\hline Labour productivity & .308 & .322 & .357 & .351 & .363 & .422 & .411 & .424 & .404 & .450 & .447 & .452 & .434 & .458 \\
\hline in $\%$ & 62.3 & 64.4 & 68.8 & 67.8 & 69.3 & 72.4 & 74.0 & 74.9 & 74.2 & 76.2 & 77.2 & 75.8 & 74.9 & 77.8 \\
\hline Labour utilization & .029 & .016 & .020 & .021 & .018 & .014 & .015 & .016 & .019 & .019 & .019 & .024 & .026 & .025 \\
\hline in $\%$ & 5.9 & 3.3 & 3.8 & 4.1 & 3.4 & 2.4 & 2.8 & 2.8 & 3.6 & 3.1 & 3.3 & 4.1 & 4.6 & 4.2 \\
\hline \multicolumn{15}{|c|}{ Employment changes } \\
\hline Employment rate & .083 & .081 & .070 & .071 & .079 & .082 & .066 & .053 & .047 & .051 & .055 & .057 & .059 & .055 \\
\hline in $\%$ & 16.8 & 16.3 & 13.5 & 13.7 & 15.1 & 14.1 & 11.9 & 9.3 & 8.6 & 8.7 & 9.5 & 9.6 & 10.1 & 9.4 \\
\hline $\begin{array}{l}\text { Labour parti-cipation } \\
\text { rate }\end{array}$ & .075 & .080 & .072 & .075 & .064 & .065 & .063 & .073 & .074 & .071 & .058 & .063 & .060 & .051 \\
\hline in $\%$ & 15.1 & 16.1 & 13.9 & 14.4 & 12.2 & 11.1 & 11.3 & 12.9 & 13.5 & 12.0 & 10.0 & 10.5 & 10.4 & 8.7 \\
\hline
\end{tabular}

Source: authors' own work based on Eurostat (2015)

GDP per capita it is not clear whether at the end of the 2000-2013 period the disparities had a tendency to stabilize (as in the case of Hungarian regions), or whether we could rather talk about their ongoing accretion (as in the case of Polish regions). In any case, based on our measurements there is no evidence speaking in favour of the beginning of convergence (as is the case in Czech regions).

Based on the breakdown we can repeat the general assertion, which is valid for all the Visegrad Group countries and that proclaims the Labour productivity factor to be clearly the dominant component of disparities in the economic productivity among their regions. The disparities in Labour productivity among Slovak regions grew both before and after Slovakia joined the EU, i.e. throughout the 2000-2013 period, and at the same time the proportion of these disparities contributing to the disparities in GDP per capita were also increasing. In the case of the Labour utilization factor the development of disparities among Slovak regions seems to be the most different in comparison with other countries of the Visegrad Group. It is, in terms of its extent, the least determining factor within the GDP per capita; however, although in the case of Czech, Hungarian, and Polish regions we can speak about convergence or at least a stable development of the Labour utilization factor, the extent of disparities among Slovak regions seems to rather increase in the post- entry period, which is reflected in the increasing contribution to the GDP per capita disparities and therefore, to a certain extent, their growth.

The demographic and economic factors of disparities among Slovak regions, i.e. Employment rate and Labour participation rate, are characterized by a very similar development - both went through a decline in regional disparities, and thus to a decline in the economic performance disparities. Both the absolute and the percentage contributions of the Employment rate factor to the GDP per capita disparities are the highest among the Visegrad Group countries. The development of the Labour participation rate disparities among Slovak regions can be, to some extent, compared to Hungarian regions in terms of their absolute contribution to the GDP per capita disparities. However, in terms of percentage the impact of the Labour participation rate factor is lower due to higher disparities in GDP per capita among Slovak regions.

\subsection{A Cross Country Comparison}

With all the above mentioned results in mind, we can state that Labour productivity is unambiguously the most important factor of regional disparities in economic performance across the Visegrad Group countries, since its contribution dominates over the other components in all the countries. This result is 
in one line with some other studies (Cuaresma et al, 2012; Barro \& Sala-i-Martin, 2004; Gardiner et al, 2004; etc.). Moreover, we have found its increasing figures both in absolute terms as well as relative to disparities. Those simple facts suggest the impact of disparities in Labour productivity is becoming more important over time; meanwhile it is increasing the gap between regions. The situation in the Labour utilization component is completely opposite to the previous case. The contribution of Labour utilization factor to regional disparities in growth is very low and mostly tends to convergence. Nevertheless, its low importance within the disparity process is not strong enough to compensate for the increase due to the divergence in Labour productivity. See Appendix 1 for visual comparison of disparities in the GDP growth by components.

The contribution of Employment indicators - Employment rate and Labour participation rate - to disparities between Visegrad Group states is rather minor. The results are much more variegated in booth its contributions as well as trends in disparity process between the countries of Visegrad Group. Even though the general patterns are not so obvious in the Employment components, another important finding has been revealed. The EU accession seems to have catalysed some changes in the previous trends (this is not so obvious from Tabs. 2-5; see Appendix 1 for better recognition of those changes). However, these changes had only little impact on the development of regional disparities in economic performance of Visegrad Group countries.

\section{Conclusion}

The aim of this paper was to assess the development of disparities in the economic performance of regions of the Visegrad Group countries, to identify how the individual factors of economic growth determine these disparities, and also to assess whether the integration of the Visegrad Group countries into the European Union affected the development of regional disparities in these countries.

Based on the analysis of the development of regional disparities in the Visegrad Group countries it can be argued that during the period 2000-2013 the regions converged, in general, to the EU 28 average, with the exception of only two metropolitan regions (Bratislava, Prague). However, when comparing a shorter period
(2004-2013), which reflects the integration of the Visegrad Group countries into the EU, we can say that after joining the EU, the measured trends varied considerably among individual countries. While in the Czech and Hungarian regions there were rather deceleration trends measured (in the case of a large number of Czech regions and a few Hungarian regions they even moved towards a divergence with values below the EU 28 average), in Slovak and Polish regions the convergence trend toward EU 28 was rather steady (in the case of several Polish regions they even slightly accelerated). Therefore, the effect of the Visegrad Group countries joining the EU seems generally contradictory from this point of view; the effect on the convergence of Czech and Hungarian regions seems to be rather negative, while in the case of the Polish and Slovak regions rather positive.

In terms of using $\sigma$-convergence to measure disparities between regions of the Visegrad Group countries it can be stated that from the transnational perspective across the whole Visegrad Group there was an increase in disparities culminating in 2007 , followed by a turn towards convergence, and in 2011 the extent of disparities reached the values of 2004 , thus, in the subsequent period the extent of regional disparities in the Visegrad Group countries was lower than before their accession to the EU. However, the question is to what extent can the convergence be attributed to the countries joining the EU, and to what extent did the economic crisis have different affects on the economies of individual countries. In terms of intranational disparities we can only come to conclusions about convergence in the case of the Czech regions. Regarding Hungarian and Slovak regions we can possibly talk about a stabilization of the extent of disparities, or their oscillation in the range of percentage units with no further increase, but at the same time we cannot unambiguously say that a downward trend has started. Polish regions show a completely different development; the growth of disparities only started after Poland's entry into the EU, but based on the measurements it is obvious that the stabilization of disparities, let alone convergence, has not yet taken place there. Generally it can be said that the Visegrad Group regions have converged, but internally the disparities within the Visegrad Group countries have rather grown or stagnated. 
Only in the case of the Czech Republic regions we can think about an initiation phase of convergence. These conclusions are quite significant regarding the application and configuration of regional policy tools, especially as they are somewhat surprising; on the other hand, they are consistent with several other studies that also record similar anomalies in terms of regional convergence within the EU.

In the context of the analysis of natures of disparities within the Visegrad Group it is possible to discern disparities in productivity expressed as GDP per hour worked as the main determinant of regional disparities in economic performance. This fact surely cannot be surprising as other authors have previously come to the same conclusion after analyzing the sources of economic growth. However, what is rather surprising is the large diversity among regions in different countries of the Visegrad Group, both in terms of the extent of variability of individual natures of economic performance determinants and in terms of their trends. In the Czech Republic, Hungary, and Slovakia, the proportion attributable to Labour productivity in terms of regional disparities clearly rose throughout the monitored period (2000-2013) - in 2013 it accounted for more than $75 \%$ of the disparities in GDP per capita among Hungarian and Slovak regions, and almost $85 \%$ among Czech regions. Conversely, in the Polish regions a lower and relatively stable proportion of disparities in Labour productivity among the GDP per capita disparities was measured, which oscillated around $60 \%$. In terms of regional disparities in Labour utilization it is true for all the countries that this factor has been contributing to the GDP per capita disparities by only a very small proportion. At the same time it can be argued that in terms of the development of Labour utilization all regions of the Visegrad Group countries, with the exception of Slovakia, displayed convergence.

It can generally be said that the development of growth disparities in the context of the Employment indicators contributes to the existence of disparities in the economic performance of regions in a rather minor way; however, due to the substantial influence of Productivity this is quite logical. In terms of disparities in Employment rate it can be stated that among regions of all countries, except Hungary, there was a convergence as well as a contribution to the GDP per capita disparities.
In the context of the Labour participation rate the convergence tendencies and declining contribution to the economic disparities are evident among Czech, Hungarian, and Slovak regions, while in the case of Hungarian and Slovak regions the initial extent of disparities and the following intensity of the convergence process were larger. In contrast, the Polish regions displayed regional divergence in terms of Labour participation rate and at the same time a growth in the contribution of this indicator to the development of GDP per capita disparities. Based on this fairly definite conclusion it can be argued that the causes of disparities growth among Polish regions do not originate in Productivity changes, as is the case in other Visegrad Group countries, but are the result of divergence in the Labour participation rate.

In terms of the accession of the Visegrad Group countries into the EU there have been certain changes in the sources of regional disparities measured, but these changes are rather minor and had only little impact on the development of disparities in economic performance. In terms of the development of Labour productivity and other, at least initially, significant determinants of regional disparities, among which for all countries, except the Czech Republic, Labour participation rate belongs, it seems that, with the exception of Poland, the existing trend started in the period before the accession of the Visegrad Group countries to the EU. Data on Polish regions indicate that a significant change in the development of Labour participation rate only occurred around the 2004 period.

In the end we can, with respect to the above findings, perhaps briefly summarize that there are some similarities but also some quite fundamental differences in the development of disparities in the economic performance of regions within the Visegrad Group countries. Generally, the most important determinant of economic disparities are the disparities stemming from the Labour productivity factor, where regions, with the exception of Poland, diverge, while in terms of other examined natures of disparities they rather converge. The impact of Labour productivity on the extent of regional disparities in economic performance has grown for the majority, while other factors have been contributing to disparities at a declining rate. At the same time we can 
say that the country, whose development of regional disparities is most deflected from others, is Poland. In terms of the impact on regional convergence of the Visegrad Group countries entering the EU it is not possible to come to a definite conclusion. Although, in terms of economic performance almost all regions of the Visegrad Group countries clearly converged to the EU 28 average value and in terms of the Visegrad Group as a whole, the question is how much of this convergence is due to the EU integration and how much is due to other factors that indisputably had an influence on economic performance. It should also be noted that in the absence of data we conducted research based on the basic breakdown of growth, which does not reflect changes in technological development nor quantitative and qualitative changes in the structure of regional capital. Nonetheless, due to the confirmation of the assumption that changes in the population characteristics affect the development of disparities in a rather minor way, and at the same time the development within these demographic factors rather speak in favour of convergence trends, it is clear that detailed research into the breakdown of the equity component of growth would undoubtedly be very desirable.

The University of Pardubice, Faculty of Economics and Administration, Project SGSFES_2015001, financially supported this work.

\section{References}

Applová, P. (2014). Effect of EU enlargement on the level of achieved convergence. In V. Klimova, \& V. Zitek (Eds.), $17^{\text {th }}$ International Colloquium on Regional Sciences. Conference Proceedings (pp. 62-68). Brno: Masarykova univerzita. doi:10.5817/CZ.MUNI.P210-68402014-6.

Armstrong, H. (1995). Convergence among Regions of the European Union. Papers in Regional Science, 74(4), 143-152. doi:10.1111/j.1435-5597.1995.tb00633.x.

Balassa, B. (1961). The Theory of Economic Integration. Homewood: R. D. Irwin.

Baldwin R., \& Wyplosz, C. (2006). The economics of European integration. London: McGraw-Hill.

Barca, F. (2009). An Agenda for a Reformed Cohesion Policy: A place-based approach to meeting European Union challenges and expectations. Brussels: European Commision. Retrieved from: http://www.europarl.europa. eu/meetdocs/2009_2014/documents/regi/dv/ barca_report_barca_report_en.pdf.

Barro, R., \& Sala-I-Martin, X. (2004). Economic Growth. London: The MIT Press.

Baumol, W. (1986). Productivity Growth, Convergence, and Welfare: What the Long-Run Data Show. The American Economic Review, 76(5), 1072-1085.

Baumol, W., Nelson, R., \& Wolff, E. (1994). Convergence of Productivity: Cross-National Studies and Historical Evidence. New York: Oxford University Press.

Ben-David, D. (1999). Trade, Growth and Disparity among Nations. In H. Nordstrom, D. Ben-David, \& A. Winters (Eds.), Trade Income Disparity and Poverty (pp. 11-37). Geneva: WTO.

Capello, R. (2007). Regional Economics. Devon: Florence Production Ltd.

Cuaresma, J., Oberhofer, H., Smits, K., \& Vincelette, G. (2012). Drivers of Convergence in Eleven Eastern European Countries (Policy Research Working Paper 6185). Washington D.C.: The World Bank. doi:10.1596/1813-94506185.

Cuaresma, J., Oberhofer, H., \& Vincelette, G. (2014). Institutional barriers and job creation in Central and Eastern Europe. IZA Journal of European Labor Studies, 3(3), 1-29. doi:10.1186/2193-9012-3-3.

Dobrinsky, R., \& Havlik, P. (2014). Economic Convergence and Structural Change: the Role of Transition and EU Accession (WIIW Research Report 395). Vienna: WIIW.

EU. (2010). Consolidated Versions of the Treaty on European Union and the Treaty of the Economic Functioning of the European Union. Luxembourg: Publications Office of the European Union.

European Commission. (2015). Is my region covered? Retrieved October 10, 2015, from http://ec.europa.eu/regional_policy/en/ policy/how/is-my-region-covered.

Eurostat. (2015). Database. Retrieved July 15, 2015, from http://ec.europa.eu/eurostat/ data/database.

Fárek, J., \& Kraft, J. (2006). Světová ekonomika: za prahem nového století globálních změn (vstup do 21. století). Liberec: Technická univerzita $v$ Liberci.

Fischer, S., Sahay, R., \& Vegh, C. (1998). From transition to market: Evidence and growth 
prospects (IMF Working Paper 52). Washington: International Monetary Fund.

Forgó, B., \& Jevčák, A. (2015). Economic Convergence of Central and Eastern European EU Member States over the Last Decade (2004-2014) (European Economy Discussion Paper 001). Luxembourg: Publications Office of the European Union. doi:10.2765/89677.

Fujita, M., \& Krugman, P. (2004). The new economic geography: Past, present and the future. Papers in Regional Science, 83(1), 139164. doi:10.1007/s10110-003-0180-0.

Gardiner, B., Martin, R., \& Tyler, P. (2004). Competitiveness, Productivity and Economic Growth across the European Regions. Regional Studies, 38(9), 1045-1067. doi:10.1080/003434 0042000292638.

Geppert, K., Happich, M., \& Stephan, A. (2008). Regional Disparities in the European Union: Convergence and Agglomeration. Papers in Regional Science, 87(2), 193-217. doi:10.1111/j.1435-5957.2007.00161.x.

Jovanovich, M. (2005). The Economics of European Integration. Cheltenham: Edward Elgar.

Kraftová, I., Matěja, Z., \& Prášilová, P. (2011). Economic performance: Variability of businesses within each industry and among industries. Engineering Economics, 22(5), 459467. doi:10.5755/j01.ee.22.5.964.

Krugman, P., \& Venables, A. (1990). Integration and the competitiveness of peripheral industry. In C. Bliss, \& B. de Macedo (Eds.), Unity with diversity in the European economy: The Community's Southern frontier (pp. 56-74). Cambridge University Press.

Krugman, P. (1991). Geography and Trade. Cambridge: The MIT Press.

Krugman, P. (1997). The Age of Diminished Expectations: U.S. Economic Policy in the 1990s. Cambridge: MIT Press.

Lucas, R. (1988). On the Mechanics of Economic Development. Journal of Monetary Economics, 22(1), 3-42. doi:10.1016/03043932(88)90168-7.

Machlup, F. (1977). A History of Thought on Economic Integration. New York: Columbia University Press.

Martín, C., Velázques, F., \& Funck, B. (2001). European Integration and Income Convergence: Lessons For Central And Eastern European Countries (World Bank Technical Paper 514). Washington D.C.: The World Bank. Retrieved July 10, 2015, from https://openknowledge.worldbank.org/ bitstream/handle/10986/13968/multi0page. pdf? sequence $=1$.

Marzinotto, B. (2012). The Growth Effects of EU Cohesion Policy: A Meta-analysis (Bruegel Working Papers 2012/14). Brussels: Bruegel. Retrieved July 8, 2015, from http://bruegel. org/wp-content/uploads/imported/publications/ WP_2012_14_cohesion_2_.pdf.

Monfort, P. (2008). Convergence of EU regions: Measures and evolution. European Union Regional Policy (European Union Regional Policy Working papers 01/2008). Brussels: European Commision. Retrieved July 18, 2015, from http://ec.europa.eu/regional_ policy/sources/docgener/work/200801_ convergence.pdf.

OECD. (2015a). Jobs - OECD Data. Retrieved July 12, 2015, from https://data.oecd. org/jobs.htm\#profile-Employment.

OECD, (2015b). OECD Compendium of Productivity Indicators 2015. Paris: OECD Publishing.

Olofsdotter, K., Torstensson, J. (1998). Economic integration, market size and the welfare effects of trade liberalisation. Weltwirtschaftliches Archiv, 134(2), 302-319.

Ottaviano, G., \& Puga, D. (1998). Agglomeration in the global economy: a survey of the new economic geography. World Economy, 21(6), 707-731. doi:10.1111/14679701.00160.

Perroux, F. (1969). L'Économie du XXe siècle. Paris: Presses universitaires de France.

Quah, D. (1996). Convergence Empirics Across Economies with Some Capital Mobility. Journal of Economic Growth, 1(1), 95-124.

Skokan, K. (2004). Konkurenceschopnost, inovace a klastry $v$ regionálním rozvoji. Ostrava: Repronis.

Solow, R. (1956). A Contribution to the Theory of Economic Growth. The Quarterly Journal of Economics, 70(1), 65-94.

Solow, R. (1957). Technical Change and the Aggregate Production Function. The Review of Economics and Statistics, 39(3), 312-320.

Stiglitz, J. (1999). Whither Reform? Ten Years of the Transition. In B. Pleskovic, \& J. Stiglitz (Eds.), Annual World Bank Conference on Development Economics (pp. 1-32). Washington D.C.: World Bank.

Tvrdoň, M. (2010). Makroekonomická konvergence: prípad zemí Visegrádské čtyřky. Scientific papers of the University of 


\section{Ekonomie}

Pardubice. Series D, Faculty of Economics and Administration, 16(1), 316-328.

Tvrdoň, M., Tuleja, P., \& Verner, T. (2012). Ekonomická výkonnost a trh práce v kontextu ekonomické krize: zkušenosti ze zemí Visegradské čtyřky. E\&M Ekonomie a Management, 15(3), 16-30.

Vintrová, R., \& Žd'árek, V. (2007). Vztah reálné a nominální konvergence $v C \breve{R}$ a nových členských zemích EU (WorkingPaper CES VŠEM 8/2007). Praha: CES VŠEM.

Zdražil, P. (2014). The Influence of Innovation Potential on Living Conditions Development of Central and Eastern European Countries Population. In V. Klimova, \& V. Zitek (Eds.), $17^{\text {th }}$ International Colloquium on Regional Sciences. Conference Proceedings (pp. 209-216). Brno: Masarykova univerzita. doi:10.5817/CZ.MUNI.P210-6840-2014-25.
Zdražil, P., \& Kraftová, I. (2012). Do the V4 Regions Converge?. $15^{\text {th }}$ International Colloquium on Regional Sciences. Conference Proceedings (pp. 48-58). Brno: Masarykova univerzita.

Ing. Pavel Zdražil, Ph.D. University of Pardubice Faculty of Economics and Administration Institute of Regional and Security Sciences

Pavel.Zdrazil@upce.cz

Ing. Petra Applová

University of Pardubice

Faculty of Economics and Administration Institute of Regional and Security Sciences

Petra.Applova@upce.cz 


$$
-\mathrm{V} 4 \rightarrow \mathrm{CZ} \rightarrow \mathrm{x}-\mathrm{HU}+\mathrm{PL}-\mathrm{SK}
$$

\section{Labour productivity}

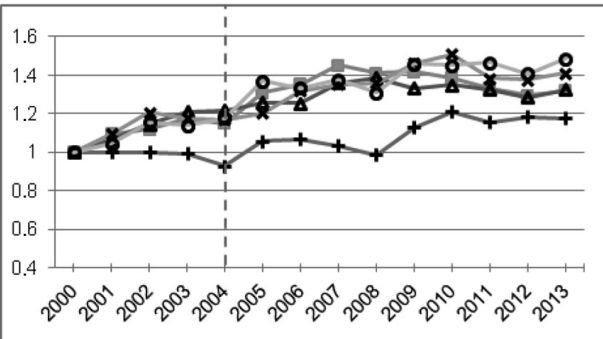

Source: authors' own work based on Eurostat (2015)

\section{Employment rate}

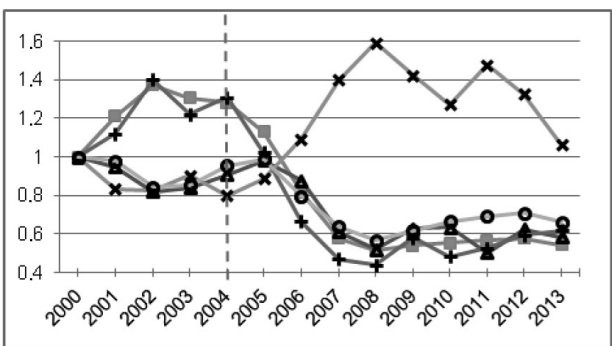

\section{Labour utilization}

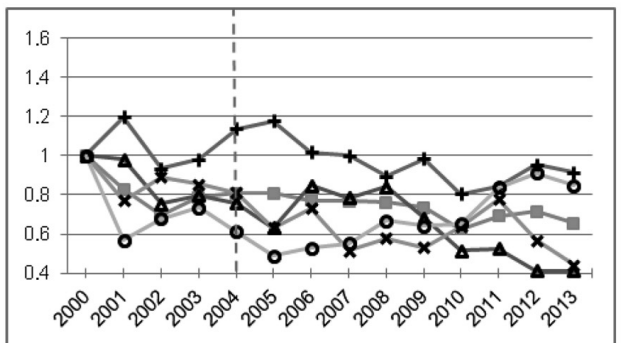

Labour participation rate

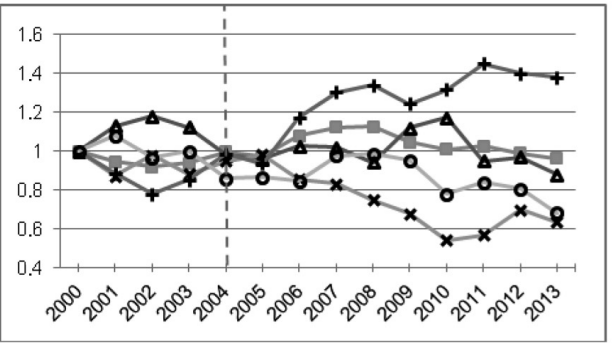

Source: authors' own work based on Eurostat (2015) 


\title{
Abstract
}

\section{GROWTH DISPARITIES AMONG REGIONS OF THE VISEGRAD GROUP COUNTRIES: AN EVIDENCE OF THEIR EXTENT AND NATURE}

\author{
Pavel Zdražil, Petra Applová
}

The deepening of regional disparities is an issue of increasing importance that has been systematically emphasized in the EU policy, especially since the process of "Eastern Integration" has started. The paper focuses on the Visegrad Group countries whose regions are less developed in the EU context. The aim of the research is to assess the development of disparities in regional economic performance of the Visegrad Group countries, to identify how the factors of economic growth determine these disparities, and partly to assess whether the integration of the Visegrad Group countries into the EU influenced the development of regional disparities in these countries. For the analysis of disparities during 2000-2013 we selected an approach of measuring real convergence (sigma-convergence). Disparities were measured in the context of a breakdown of the GDP per capita into sub-components, reflecting on the development of disparities in productivity and employment.

The results show that, although regions of the Visegrad Group countries converged towards the EU average and also in terms of the Visegrad Group as a whole, regional disparities within countries rather increased. This led to a paradox where, although the objective of reducing regional disparities across the EU was satisfied, from a national perspective disparities increased. The Labour productivity factor, with its dominant yet steadily growing contribution, is the main determinant of disparities in the performance of the Visegrad Group regions. Other sources of disparities are characterized by a stable development or convergence. Only Polish regions deviated from the general conclusions, since the extent of disparities among them grew constantly, and the nature of disparities was the Labour participation rate. In terms of the impact caused by accession into the $E U$, the measured changes were rather minor and the identified trends had mostly been in place before the Visegrad Group countries entered the EU.

Key Words: Visegrad Group, Central Europe, regional disparities, productivity, growth, EU enlargement.

JEL Classification: R11, 047.

DOI: 10.15240/tul/001/2016-2-003 